REVISTA de

PEDAGOGIE

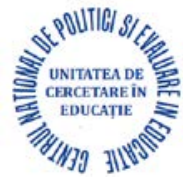

JOURNAL of
PEDAGOGY

http://revped.ise.ro

Print ISSN 0034-8678; Online ISSN: 2559 - 639X

\title{
WEBLOGS IN THE TRAINING OF GERMAN-SPEAKING TEACHERS IN ROMANIA - PLANNING, DESIGN, IMPLEMENTATION, EVALUATION AND DISCUSSION USING THE EXAMPLE OF PROF-ES.COM
}

Blogurile în formarea profesorilor vorbitori de limba germană din Romania - proiectare, design, implementare, evaluare și discuții pe baza exemplului prof-es.com

\section{Diana ZOPPELT, Adriana HERMANN}

\author{
Journal of Pedagogy, 2020 (2), 31 - 48 \\ https://doi.org/10.26755/RevPed/2020.2/31
}

The online version of this article can be found at: http://revped.ise.ro/en/2020/

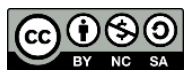

This work is licensed under the Creative Commons Attribution-NonCommercial-ShareAlike 4.0 International License.

To view a copy of this license, visit http://creativecommons.org/licenses/by-nc-sa/4.0/ or send a letter to Creative Commons, PO Box 1866, Mountain View, CA 94042, USA

Published by:

Centrul Național de Politici și Evaluare în EduCație

UNiTATEA DE CERCETARE ÎN EDUCAȚIE

http://www.ise.ro/

https://rocnee.eu/

Further information about Revista de Pedagogie - Journal of Pedagogy can be found at:

Editorial Policy: http://revped.ise.ro/editorial-policy/

Author Guidelines: http://revped.ise.ro/en/author-guidelines/ 


\title{
WEBLOGS IN THE TRAINING OF GERMAN- SPEAKING TEACHERS IN ROMANIA - PLANNING, DESIGN, IMPLEMENTATION, EVALUATION AND DISCUSSION USING THE EXAMPLE OF PROF-ES.COM
}

\section{Diana Zoppelt*}

\author{
Pedagogical Highschool "Andrei Şaguna”, \\ Sibiu, Romania \\ diana_zoppelt@yahoo.com
}

Adriana Hermann**

Center for Teacher Training in German,

Mediaş, Romania

adrianahermann@zfl.ro

\begin{abstract}
The present study deals with the use of a weblog in the further training of teachers at Romanian public schools with German teaching. The question whether an educational blog meets the needs, wishes and expectations of the target group was investigated using the IMMS questionnaire based on the ARCS model by Keller $(1983,1987)$. The evaluation results show a positive impact of the blog on the study participants and point out the importance of motivational factors in designing online learning content. This referred to the multimedia narrative presentation and the clear structuring of current psycho-educational topics with practical relevance for the target group.
\end{abstract}

Keywords: ARCS model, blog, further training, motivational design, online learning.

\footnotetext{
* Teacher for Pedagogy and Psychology, Pedagogical Highschool “Andrei Şaguna”, Sibiu, Romania.

** Teacher Trainer, Center for Teacher Training in German, Mediaş, Romania.
} 


\section{Rezumat}

Această cercetare a avut ca obiect de studiu organizarea activită ii de dezvoltare profesională a cadrelor didactice din învă ământul cu predare în limba germană din România prin intermediul unui blog. Scopul cercetării a fost de a evalua cu ajutorul chestionarului IMMS, elaborat în cadrul modelului ARCS (Keller, 1983, 1987), dacă un blog folosit în context educa ional informal este în măsură să vină în întâmpinarea nevoilor, dorin elor şi aşteptărilor grupului intă mai sus men ionat. Rezultatele evaluării arată un impact pozitiv al blogului asupra participan ilor la studiu şi scoate în eviden ă importan a factorilor motiva ionali în designul con inuturilor de învă are online. Printre aceşti factori se numără prezentarea multimedială narativă şi structurarea clară a unor subiecte psihopedagogice de actualitate, cu relevan $\breve{a}$ practică pentru grupul intă.

Cuvinte-cheie: blog, design motiva ional, dezvoltare profesională, învă are online, modelul ARCS.

\section{Introduction}

The socio-political reform in Romania, which has been going on for the last 30 years, has had a rather negative impact on the education system as, among other things, the Romanian results of the last PISA study show (OECD, 2019). The intended curricular and methodological changes often failed because of the incoherence of the educational policy measures. To make permanent and successful modernization of the Romanian education system happen there is, among others, a strong need for adequate training of psycho-pedagogical skills for the teachers (Proiect al Preşedintelui României Klaus Johannis, România Educată, 2018, p. 9). From that point of view teachers are under pressure to attend accredited training but the time and freedom to look at quality, to assess quality and to demand it are massively limited. Due to various access limitations to good training opportunities and in absence of guidance about professional development through proper knowledge management in communities of practice, many teachers find themselves left alone and are discouraged (Zoppelt et al., 2015). As a result teachers are less motivated to take in consideration informal further training offers which negatively influences their professional performance and thus reduces the chances of real progress for the desired educational reform. Considering these facts, the use of digital tools accessible on the Internet to 
provide further training for teachers may be part of the solution to the problems mentioned above.

There is empirical evidence that the systematic use of weblogs for online informal educational purposes can be an impetus to bring out considerable learning effects in adults (Churchill, 2009; Glogoff, 2005; Kerawalla et al., 2009; Moore et al., 2010). Adult learners benefit from web-based learning arrangements as informal education alternatives that enable them to access information and social networks online (Hsu \& Wang, 2010; Selwyn, 2007). With regard to learning, Heo and Lee (2013) identify three dimensions of informal learning activities for adults in Web 2.0: (a) an acquisition process of new information (b) a reflection process regarding personal experiences from everyday work and (c) a practice-oriented community process that refers to knowledge-sharing through social networking for cooperative problem solving and decision making.

The blog is a participative Web 2.0 tool that enables mobile learning and is suitable for the implementation of both cognitivist and socio-constructivist theoretical assumptions about learning. Didactically relevant features, such as personalization, learner focus, and situational, lifelong, ubiquitous learning can be successfully implemented via blogging (Sharples et al., 2005). The learners can actively expand their own existing knowledge through an active examination of the blog content and deepen this in a critically reflected social dialogue using the blog's comment function (De Witt \& Czerwionka, 2007, p. 56). A blog used for educational purposes therefore fulfills three functions: mediating factual knowledge (receptive learning), providing direct guidance as feedback on learners' comments (directive learning) and promoting selfdirected information processing (discovery learning) (Glogoff, 2005). The results of a Korean study by Park et al. (2011) show that the majority of adults noticed positive changes, including learning experiences in everyday life after blogging. Bloggers felt that blogging was primarily an acquisition and/or reflection-oriented learning process. In addition, adult bloggers identified the features of learning through blogging as "self-directed", "practical", "situative", "unlimited and accessible" and "self-regulated" (ebd., 2011). Chawinga (2017) found in his evaluation study that blogging and microblogging are suitable for educational purpose, since learners used this technology to exchange and discuss course materials, publish their course 
reflections, and interact with each other and with their lecturers in a timely manner.

In this study an educational blog for teachers of Romanian public schools with German teaching was developed and used in the form of a digital platform for regularly published articles in German on current didactic and psychological topics between December and March 2020. The blog was introduced to the target group in a pilot phase lasting 3 months. Subsequently, there was a measurement of the motivation level of the blog users to see if it was well received and useful in satisfying the users' learning needs. In order to measure the motivation level of the blog users the ARCS model of motivational design by Keller (Keller, 1987, 2010; Keller \& Suzuki, 2004) was used. This model is based upon the idea that there are four key elements in the learning process which have a significant impact on developing really engaging digital learning tools: Attention (gaining and maintaining learners' attention), Relevance (establishing relevance for the goals and needs of the learners), Confidence (providing confidence regarding goal achievement) and Satisfaction (adequately rewarding learning outcomes). Research done over the past two decades has established the ARCS model as an important theoretical and empirical tool for motivational optimization in the area of te-learning and implicitly online learning. ChanLin (2009) applied e.g. the motivation analysis in a web-based course and reported that the ARCS model is suitable for the diagnosis of motivational problems of the learners and the search for course improvements. Pittenger and Doering (2010) found that implementing motivational design in online courses can improve their completion rate. Further study results indicated that the two factors Attention and Relevance have particularly strong effects on encouraging and sustaining learners' motivation (Cook et al., 2009; Naime-Diefenbach, 1992; Nwagbara, 1994).

\section{Methodology}

\subsection{Target group}

The target audience for the training blog was made up of German public school teachers in Romania at all school levels (pre-school, primary and secondary). These teachers are largely Romanian who are graduates of the 
German-language educational path and have excellent knowledge of the German language. A smaller part is made up of representatives of the German minority in Romania and teachers sent by Germany. The age of the target group corresponds to the legal professional age and varies from 19 to 65 years. Around $85 \%$ of the target group is female, the male proportion accordingly low (National Institute for Statistics in Romania, 2015). Most of the target group's teachers are civil servants in public kindergartens or Romanian schools with teaching in German; only a small proportion are employees with fixed-term contracts. Regarding the education level, the nationwide data collection from 2013 shows that 127 young professionals have a high school or university degree, 182 have passed the "Definitivat" as the first qualification level in their professional life, 166 have acquired degree II (medium qualification level) and 269 have acquired degree I (highest qualification level) (Hermann, 2014).

For this study, the number of potential blog users nationwide was estimated at around 50 to 100, mostly female participants in young or middle adulthood who are familiar with common Internet functions and have Internet access. It was assumed that the users had little experience with online learning, but were rather positive about it due to the advantages of mobile learning. Visiting the blog was considered an informal learning measure on a voluntary basis. The learning time available was estimated to be low, since it concerns fulltime employees. In view of the limited learning time and the lack of experience with online learning, as well as the high motivational demands of self-directed learning, it was assumed that the readiness of the users to read the blog was low to moderate.

\subsection{Didactic design and implementation of the blog}

The blog, called "ProfEssentials - Inspiration for teachers: Dare, think, act", is a platform created in WordPress on which articles with psycho-educational learning content were regularly uploaded every two weeks during the 6 week study phase. The educational focus relayed on promoting those professional competencies that make teachers personally strong and strengthen the relationship with their students, helping them work successfully in class. 
In order to ensure the blog acceptance, the content was designed in conformity with a learning-centered didactical approach implementing two of the four ARCS criteria for successful media design (Keller, 1983, 1987). In order to increase the interest of the users and motivate them to regularly read the blog the Attention and Relevance ARCS criteria were choosed to properly design the weblog (Tab. 1). These two criteria have been shown to produce particulary strong effects on motivation. Regarding attention, news effects and the variation in content and method influence the learner's reactions to the subject matter. Relevance strategies (goal orientation and familiarity) proved to be particularly effective when learning materials were originally judged to be of little relevance. (Naime-Diefenbach, 1992; Nwagbara, 1994; Cook et al., 2009).

Table no. 1. Attention and Relevance ARCS criteria for successful media design (Keller, 1983)

\begin{tabular}{|c|c|c|}
\hline \multicolumn{2}{|c|}{ ARCS motivational criteria } & Didactic strategy \\
\hline \multirow{3}{*}{ Attention } & Perceptual Arousal & $\begin{array}{l}\text { - stimulating audio-visual effects } \\
\text { - specifically illustrated examples } \\
\text { - novelty and surprise } \\
\text { - incongruency and conflicting perspectives }\end{array}$ \\
\hline & Inquiry Arousal & $\begin{array}{l}\text { - learners activation and stimulation of curiosity } \\
\text { by posing questions or problems to solve }\end{array}$ \\
\hline & Variability & $\begin{array}{l}\text { - methods and media to meet learners' various } \\
\text { needs (e.g. videos, advance organizer, chats) }\end{array}$ \\
\hline \multirow{3}{*}{ Relevance } & Goal Orientation & $\begin{array}{l}\text { - presentation of the objectives and useful purpose } \\
\text { of instruction } \\
\text { - use of specific methods for the successful } \\
\text { achievement of the goals }\end{array}$ \\
\hline & Motive Matching & $\begin{array}{l}\text { - objectives match the learners needs and motives } \\
\text { - freedom to choose a learning strategy }\end{array}$ \\
\hline & Familiarity & $\begin{array}{l}\text { - presentation of the content in ways that are } \\
\text { understandable } \\
\text { - content that is related to the learners' } \\
\text { experiences and values }\end{array}$ \\
\hline
\end{tabular}

Didactically designing the blog content according to the ARCS motivational criteria included the following measures:

1. Links on the homepage of the blog to present the learning objectives and the author's career in order to ensure motive adaptation and familiarity (Relevance). 
2. Choosing topics with high novelty and regarded as useful by the target audience, such as positive discipline, learning skills or the new kindergarten curriculum in Romania (Attention and Relevance).

3. Presenting case studies in a narrative manner at the beginning of the most articles and referring to familiar situations from the everyday professional life of teachers (Attention and Relevance).

4. Dealing with topics from multiple and conflicting perspectives, some of which were already included in the title (Attention).

5. Open questions, often at the end of the article, to stimulate the active participation of learners through exchange of experiences and opinions in the comment section (Attention).

6. Posts containing in addition to the texts links to further internet sources and illustrative videos as well as advanced organizers with the most important terms of the article (Attention and Relevance).

7. Addressing the readers directly and personally (Attention and Relevance).

\subsection{Research questions}

This research project is a cross-sectional survey of non-experimental data with the purpose of evaluating motivational features of an educational blog based on the ARCS model by Keller $(1983,1987)$. The study participants evaluated the blog content quantitatively with regard to two motivational criteria: Attention and Relevance.

The key research questions of the study were:

1. How is the blog rated by the users regarding the two motivational ARCS criteria: Attention and Relevance?

2. Is there a relationship between the age of blog users or their web experience and the blog evaluation on the two motivational criteria?

The hypotheses were:

H1: If there was a good implementation of the didactic recommendations of the ARCS model, the evaluation of the blog content on the Attention and Relevance Scale of the IMMS will be on average over 3 on the 5-level Likert scale. 
H2: The younger/more experienced the blog users are, the higher the measured motivation level on the two IMMS scales.

H3: There are no statistically significant differences with regard to the motivational criteria - Attention and Relevance -, on the IMMS in relation with the educational level the blog users teach.

\subsection{Evaluation}

\subsubsection{Sampling and data collection}

Study participants were teachers at all educational levels from Romanian public schools with German teaching. The invitation to participate in the study came by mail, in the same way as the announcement of the blog, with the support of the Center for Teacher Training in German from Romania (CFCLG, n.d.). The participation was voluntary. The data collection took place within two weeks at the end of the 6 week study phase by conducting an online survey (UmfrageOnline, n.d.). All participants were informed about the content and aim of the study, as well as data protection and agreed to participate. Answering the questionnaire took approx. 10 minutes.

A total of 38 respondents, between the ages of 19 and 50, from various teaching areas and from all educational levels took part in the study. 11 respondents were excluded from the evaluation due to answer inconsistencies or missing data. Sample socio-demographic data on age, gender, teaching level and web experience in years are shown in Table 2. The great difference between male and female participants can be traced back to the professional profile of the respondents (National Institute for Statistics in Romania, 2015). 
Tabel no. 2. Description of the study sample

\begin{tabular}{llcc}
\hline Characteristics & & Frequency & Percent \\
\hline \multirow{2}{*}{ Gender } & female & 25 & 92.6 \\
& male & 2 & 7.4 \\
Age & under 25 & 8 & 29.6 \\
& between 25 and 34 & 2 & 7.4 \\
& between 35 and 50 & 11 & 40.7 \\
Teaching level & 50 plus & 6 & 22.2 \\
& kindergarten & 12 & 44.4 \\
& primary school & 5 & 18.5 \\
Web experience (self-rating) & secondary school & 10 & 37.0 \\
& low experience & 1 & 3.7 \\
& medium experience & 12 & 44.4 \\
& high experience & 14 & 51.9 \\
\hline
\end{tabular}

\subsubsection{Questionnaire and operationalization}

For the study purpose two scales of the IMMS (Instructional Materials Motivation Survey) (Keller 1983, 1987) were used. The IMMS is an integral part of the ARCS model and has established itself as an internally consistent and valid measuring instrument for recording of motivational features in elearning (Cook et al., 2009; Loorbach et al., 2014; Pittenger \& Doering, 2010).

The theoretical construct to be evaluated was the intrinsic motivation of the teachers to use the blog as a learning tool for their professional development. For this the Attention Scale (12 items) and the Relevance Scale (9 items) of the IMMS questionnaire were used in order to measure main motivational features of the blog. The 12 items on the Attention Scale capture the quality of the learning offer to stimulate and permanently bind the learner's attention, while the 9 items on the Relevance Scale measure the subjectively perceived significance of the blog content (Cook et al., 2009; Keller, 1987). The answer alternatives per each scale item varied on a five-point Likert scale from 1 to $5(1=$ strongly disagree, $2=$ disagree, $3=$ neutral, $4=$ agree, $5=$ strongly 
agree). Both IMMS scales were used in German translation and with items slightly adapted to the research project. There was a total of 6 reverse items that were formulated to the contrary (e.g. item M_V7 on the Relevance Scale). These were inverted using SPSS before entering data processing. The scale and item statistics are shown in Table 3.

\section{Results}

A scale reliability test was conducted to evaluate the IMMS result. Afterwards, some descriptive statistics about motivation levels were analyzed. Correlation coefficients were computed for testing the relationship between motivation levels and age or web experience. Further, an ANOVA test was arranged to check whether there was any difference in motivation levels of the participants regarding their teaching level.

\subsection{Reliability of the scales}

The reliability of the two IMMS scales used to evaluate the motivational features of the teaching blog was determined using the Cronbach Alpha. According to Streiner (2003) values of the Cronbach Alpha between 0.6 and 0.9 are acceptable, although a good test should show a reliability around 0.80 . Previous studies that determined the reliability of the IMMS scales showed a good interitem correlation with values around 0.75 (Cook et al., 2009; Huang \& Hew, 2016; Pittenger \& Doering, 2010; Loorbach et al., 2014). This value could be replicated in this study, which suggested a good reliability of both scale results: Cronbach's alpha was 0.734 for the Attention Scale, $(n=27$ on 12 items) and 0.785 for the Relevance Scale $(n=27$ on 9 items). Because it was an online survey, objectivity was guaranteed.

\subsection{Participants motivation level}

Among the 27 participants, the average measured value on the Attention Scale of the IMMS was $3.27(\mathrm{SD}=0.5)$ and on the Relevance Scale 4.00 $(\mathrm{SD}=0.45)$. The highest measured averages were 4.67 on the Attention Scale and 4.89 on the Relevance Scale. The lowest measured values were 
1.50 on the Attention Scale and 3.33 on the Relevance Scale. Only $7.3 \%$ of the study participants had average values below 3 on the Attention Scale, whereas $55,5 \%$ of the participants average scores were above 3.5 . These results indicate that blog users rated the motivational features of the educational blog on the Likert scale rather positively. See Table 3, 4 and 5 for the tabulated information.

Items 3, 7 and 10 received the highest scores on the Attention Scale, 4.30, 4.37 and 4.33 respectively. According to this data, learners were most satisfied with the multimedia presentation of the content, their novelty value and the quality of the texts. Items 5 and 9 received the highest scores on the Relevance Scale, and 4.41 and 4.44 respectively. These results show that with regard to relevance, the usefulness of the blog content and the modeling based on concrete examples were particularly appreciated.

Table no. 3. Scale and item statistics for the two IMMS scales

\begin{tabular}{|l|l|l|l|l|}
\hline Itemlabel & Item & M & SD & Alpha \\
\hline \multicolumn{1}{|l|}{$\begin{array}{l}\text { ATTENTION } \\
\text { A_V1 }\end{array}$} & $\begin{array}{l}\text { Es gab etwas Interessantes zu Beginn dieses Blogs, das } \\
\text { meine Aufmerksamkeit angeregt hat. } \\
\text { There was something interesting at the beginning of this } \\
\text { blog that caught my attention. }\end{array}$ & 4.22 & 0.97 & 0.719 \\
\hline A_V2 & $\begin{array}{l}\text { Die präsentierten Materialien fielen einem ins Auge. } \\
\text { These materials were eye-catching. }\end{array}$ & 4.11 & 0.97 & 0.709 \\
\hline A_V3 & $\begin{array}{l}\text { Die Qualität der geschriebenen Texte half mir, } \\
\text { aufmerksam zu bleiben. } \\
\text { The quality of the writing helped to hold my attention. }\end{array}$ & 4.30 & 0.87 & 0.685 \\
\hline $\begin{array}{l}\text { A_V4 } \\
\text { (reverse) }\end{array}$ & $\begin{array}{l}\text { Die Inhalte waren so abstrakt, dass es schwer war, } \\
\text { dranzubleiben. } \\
\text { This course is so abstract that it was hard to keep my } \\
\text { attention. }\end{array}$ & $\begin{array}{l}(3.85 \\
\text { A_V5 } \\
\text { (reverse) }\end{array}$ & $\begin{array}{l}\text { Die Seiten des Blogs machten einen trocknen, } \\
\text { unattraktiven Eindruck. } \\
\text { The blog content looks dry and unappealing. }\end{array}$ & 1.81 \\
\hline A_V6 & $\begin{array}{l}\text { Die Art, wie die Information auf der Seite dargeboten } \\
\text { wurde, half mir, aufmerksam zu bleiben. } \\
\text { The way the information is arranged on the pages helped } \\
\text { keep my attention. }\end{array}$ & 4.15 & 1.04 & 0.751 \\
\hline $\begin{array}{l}\text { Der Blog enthielt Informationen, die meine Neugier } \\
\text { angeregt haben. } \\
\text { This course has things that stimulated my curiosity. } \\
\text { (reverse) }\end{array}$ & $\begin{array}{l}\text { Die im Blog auftretenden Wiederholungen langweilten } \\
\text { mich manchmal. } \\
\text { The amount of repetition in this blog caused me to get } \\
\text { bored sometimes. }\end{array}$ & 2.44 & 1.28 & 0.716 \\
\hline
\end{tabular}




\begin{tabular}{|c|c|c|c|c|}
\hline Itemlabel & Item & M & SD & Alpha \\
\hline \multicolumn{4}{|c|}{ ATTENTION } & 0.734 \\
\hline A_V9 & $\begin{array}{l}\text { Ich habe manche Aussagen gelesen, die überraschend und } \\
\text { unerwartet waren. } \\
\text { I learned some things that were surprising or unexpected. }\end{array}$ & 4.19 & 0.62 & 0.714 \\
\hline A_V10 & $\begin{array}{l}\text { Die medial vielfältig dargebotene Information (Texte, } \\
\text { Bilder, Videos, Schemata) half mir, aufmerksam zu } \\
\text { bleiben. } \\
\text { The variety of reading passages, exercises, illustrations, } \\
\text { etc., helped keep my attention. }\end{array}$ & 4.33 & 0.83 & 0.735 \\
\hline $\begin{array}{l}\text { A_V11 } \\
\text { (reverse) }\end{array}$ & $\begin{array}{l}\text { Der Schreibstil war langweilig. } \\
\text { The style of writing is boring. }\end{array}$ & $\begin{array}{l}1.67 \\
(3.33)\end{array}$ & 1.07 & 0.724 \\
\hline $\begin{array}{l}\text { A_V12 } \\
\text { (reverse) }\end{array}$ & $\begin{array}{l}\text { Es gab so viele Wörter in jedem Artikel, dass es irritierend } \\
\text { wirkte. } \\
\text { There are so many words on each page that it is irritating. }\end{array}$ & $\begin{array}{l}1.79 \\
(3.21)\end{array}$ & 1.10 & 0.707 \\
\hline \multicolumn{4}{|c|}{ RELEVANCE } & 0.785 \\
\hline M_V1 & $\begin{array}{l}\text { Es ist klar für mich, wie die Bloginhalte in Beziehung zu } \\
\text { Aspekten, die ich schon kenne, stehen. } \\
\text { It is clear to me how the content of this material is related } \\
\text { to things I already know. }\end{array}$ & 4.04 & 0.71 & 0.742 \\
\hline M_V2 & $\begin{array}{l}\text { Es gab Geschichten, Bilder oder Beispiele, die mir gezeigt } \\
\text { haben, wie diese Inhalte bedeutend sein können. } \\
\text { There were stories, pictures, or examples that showed me } \\
\text { how this material could be important to some people. }\end{array}$ & 4.37 & 0.57 & 0.743 \\
\hline M_V3 & $\begin{array}{l}\text { Alle Blogartikel zu lesen, war wichtig für mich. } \\
\text { Consequently, reading the blog articles was important to } \\
\text { me. }\end{array}$ & 4.11 & 0.75 & 0.736 \\
\hline M_V4 & $\begin{array}{l}\text { Die Bloginhalte passten zu meinen Interessen. } \\
\text { The blog content was relevant to my interests. }\end{array}$ & 4.22 & 0.75 & 0.731 \\
\hline M_V5 & $\begin{array}{l}\text { Es gab Beispiele oder Erklärungen, wie die Bloginhalte } \\
\text { von den Lesern genutzt werden können. } \\
\text { There were explanations or examples of how people can } \\
\text { use the knowledge in this blog. }\end{array}$ & 4.41 & 0.57 & 0.735 \\
\hline M_V6 & $\begin{array}{l}\text { Die Inhalte und der Schriftstil der Blogartikel weckten } \\
\text { den Eindruck, dass es sich lohnt, weiterzulesen. } \\
\text { The content and style of writing in this blog convey the } \\
\text { impression that its content is worth knowing. }\end{array}$ & 4.33 & 0.88 & 0.759 \\
\hline $\begin{array}{l}\text { M_V7 } \\
\text { (reverse) }\end{array}$ & $\begin{array}{l}\text { Die Bloginhalte waren unwichtig für meine Bedürfnisse, } \\
\text { da ich die meisten schon kannte. } \\
\text { This blog content was not relevant to my needs because I } \\
\text { already knew most of it. }\end{array}$ & $\begin{array}{l}2.07 \\
(2.93)\end{array}$ & 1.00 & 0.887 \\
\hline M_V8 & $\begin{array}{l}\text { Ich konnte die Bloginhalte in Zusammenhang mit dem } \\
\text { bringen, was ich in meinem Leben gesehen, getan oder } \\
\text { gedacht habe. } \\
\text { I could relate the content of this blog to things I have } \\
\text { seen, done, or thought about in my own life. }\end{array}$ & 4.04 & 0.76 & 0.737 \\
\hline M_V9 & $\begin{array}{l}\text { Die Bloginhalte werden für mich nützlich sein. } \\
\text { The blog content will be useful to me. }\end{array}$ & 4.44 & 0.58 & 0.756 \\
\hline
\end{tabular}

$M=$ mean, $S D=$ standard deviation, sample size $: N=27$

Answer alternatives: $1=$,strongly disagree” to $5=$,strongly agree” 
Table no. 4. Average scores of motivation level on the two IMMS scales $(N=27)$

\begin{tabular}{|l|l|l|l|l|}
\hline IMMS scale & Minimum & Maximum & Mean & Std. Dev. \\
\hline Attention (12 items) & 1.50 & 4.67 & 3.2685 & .49911 \\
\hline Relevance (9 items) & 3.33 & 4.89 & 4.0041 & .44921 \\
\hline
\end{tabular}

Table no. 5. Range of motivation level

\begin{tabular}{|l|l|l|l|}
\hline Motivation level & $\begin{array}{c}\text { Medium scores on } \\
\text { both IMMS scales }\end{array}$ & $\begin{array}{l}\text { Total number } \\
(\mathbf{N}=\mathbf{2 7})\end{array}$ & Percentage \\
\hline High level & $4.00-5.00$ & $\mathrm{~N}=2$ & $7,3 \%$ \\
\hline Upper medium level & $3.50-3.99$ & $\mathrm{~N}=13$ & $48,2 \%$ \\
\hline Medium level & $3.00-3.49$ & $\mathrm{~N}=11$ & $40,7 \%$ \\
\hline Low level & $<3.00$ & $\mathrm{~N}=1$ & $3,7 \%$ \\
\hline
\end{tabular}

3.3. Relationship between age/web experience and motivation level

Bivariate correlations between the average values on the two IMMS scales and the age or web experience of the participants were calculated. The results show a significant negative correlation between age and the measured level of motivation on the Relevance Scale $(r=-0.433, p=024)$. Furthermore, the values on the two IMMS scales correlated positively with one another $(\mathrm{r}$ $=0.470, \mathrm{p}=013$ ). All other calculated correlation values were low and not significant. This indicates that the relevance of the teaching blog was rated as lower as age group increases. The positive correlation between the two IMMS scales can be interpreted as statistical evidence that they capture the same theoretical construct.

3.4. Comparison on different learner groups' motivation level

In order to determine differences in the motivation level on the two IMMS scales depending on the teaching level of the participants an ANOVA with 
three groups was arranged. The independent variable was the teaching level (preschool, primary school, secondary education) and the dependent variable, were the IMMS scale scores regarding the two motivational criteria, Attention and Relevance. The comparisons between the three groups with respect to the average attention and relevance values calculated using ANOVA showed no significant differences $(p>0.447)$. As a result, there were no statistical differences in the level of motivation of the study participants, in relationship with the teaching level.

\subsection{Limitations of the study}

This study is a case study on 27 participants' motivation levels. The motivation levels results can only represent the involved participants' perspectives. Furthermore, an undesirable consequence of the strictly voluntary participation of persons interested in the blog is that only particularly motivated respondents took part in the study, which may have to some extent skewed the results. In order to achieve more meaningful results in the future, larger samples should be examined and one could use all four IMMS scales for the measurement of the motivation level to expand the data basis for a better interpretation. Future studies should also record performance parameters (achieved learning performance) in order to demonstrate the effectiveness of the motivational design of the blog on the learning performance.

\section{Conclusion and discussion}

In the present study, the examined question was whether a blog used for psycho-educational training purposes in Romanian public schools with German teaching is positively evaluated by the target group. For the evaluation of the motivational design of the blog we used a measuring instrument developed as part of the ARCS model by Keller $(1983,1987)$. Two motivational criteria, Attention and Relevance, were considered to be particularly important for the evaluation, since they reflect important aspects of a successful informal online learning offer for adults.

The results of the study show an overall positive assessment of both 
motivational ARCS criteria. The learner motivation was above 3 using a 5level Likert scale on the Attention, as well as on the Relevance Scale of the IMMS. This confirms the first hypothesis of the study showing that the blog design was a good implementation of the didactic recommendations of the ARCS model. According to the data, the learners were the most satisfied with the quality of the learning content, the multimedia presentation and the specific content related to everyday working life and that they particularly appreciated the usefulness and quality of the blog texts.

Regarding the second hypothesis, a negative correlation between the age of the learners and the measured level of motivation could be shown on the two IMMS scales. This means that the younger the study participants, the stronger their opinion about the learning materials as being important for their interest or their work. Since almost all learners indicated a medium or high level of web experience, no relationship between the web experience and the estimated level of motivation could be demonstrated.

The group comparison by teaching level using ANOVA showed no significant differences regarding learners motivation due to their teaching level. It can thus be concluded that all respondents, regardless of their teaching level, have rated the blog positively on average. These results point to the fact, the blog was broadly appreciated as an online training offer making effective and self-paced learning possible.

The positive results of this evaluation confirm the empirical findings from other studies (Cook et al., 2009; Huang \& Hew, 2016; Keller \& Suzuki, 2004) and point out the importance of motivational aspects in designing online learning content. Online training courses for adults should be newsworthy and should meet the needs and interests of learners. A multimedia presentation of the learning content and a good text quality containing information that is relevant for everyday working life are particularly important according to the results of the study. Young teachers in particular seem to benefit from such online training programs.

To expand the generalizability of this research, further studies are needed and a larger scale of investigation covering wider populations and timelines could be conducted. 


\section{Note of thanks}

This study was designed as part of the internationally accredited master's program "Bildung und Medien: eEducation" at the Fern-Universität Hagen in Germany. For the financial support for this research project we would like to thank the Michael Schmidt Stiftung in Romania.

\section{References}

- CFCLG (n.d.). https://www.zfl.ro/ro/index.php

- ChanLin, L.J. (2009). Applying motivational analysis in a web-based course. Innovations in Education and Teaching International, 46(1), 91-103. https://doi.org/10.1080/14703290802646123

- Chawinga, W.D. (2017). Taking social media to a university classroom: teaching and learning using Twitter and blogs. International Journal for Educational Technology in Higher Education, 14(3), 1-19.

https://doi.org/10.1186/s41239-017-0041-6

- Cook, D.A., Beckman, T.J., Kris, T.G., \& Warren, T.G. (2009). Measuring motivational characteristics of courses: Applying Kellers instructional materials motivation survey to a web-based course. Academic Medicine, 84(11), 15051509. https://doi.org/10.1097/ACM.0b013e3181baf56d

- Churchill, D. (2009). Educational applications of Web 2.0: Using blogs to support teaching and learning. British Journal of Educational Technology, 40(1), 179183. https://doi.org/10.1111/j.1467-8535.2008.00865.x

- De Witt, C., \& Czerwionka, T. (2007). Mediendidaktik. Studientexte für die Erwachsenenbildung. Bielefeld: W. Bertelsmann.

- Glogoff, S. (2005). Instructional Blogging: Promoting Interactivity, StudentCentered Learning, and Peer Input. Innovate: Journal of Online Education, 1(5). https://www.learntechlib.org/p/107281/

- Heo, G.M., \& Lee, R. (2013). Blogs and social network sites as activity systems: exploring adult informal learning process through activity theory framework. Journal of Educational Technology \& Society, 16(4), 133-145.

https://www.jstor.org/stable/10.2307/jeductechsoci.16.4.133

- Hermann, A. (2014). Das deutsche Schulwesen in Rumänien - Was sagen Zahlen aus? Zeitschrift des Zentrums für Lehrerfortbildung, 27(2), 3-4.

- Hsu, C.L., \& Wang, S. (2010). The impact of using blogs on college students' reading comprehension and learning motivation. Literacy Research and Instruction, 50(1), 68-88. https://doi.org/10.1080/19388070903509177 
- Huang, B., \& Hew, F.K. (2016). Measuring learners' motivation level in massive open online courses. International Journal of Information and Education Technology, 6(10), 759-764. https://doi.org/10.7763/IJIET.2016.V6.788

- Keller, J. M. (1983). Motivational design of instruction. In C. M. Reigeluth \& A. A. Carr-Chellman (Eds.), Instructional design theories and models. An overview of their current studies. Lawrence Erlbaum Associates.

- Keller, J.M. (1987). Development and use of the ARCS model of instructional design. Journal of Instructional Development, 10(3), 2-10.

- Keller, J.M., \& Suzuki, K. (2004). Learner motivation and e-learning design: A multinationally validated process. Journal of Educational Media, 29(3), 229239. https://doi.org/10.1080/1358165042000283084

- Keller, J.M. (2010). Motivational Design for Learning and Performance: The ARCS Model Approach. Springer.

- Kerawalla, L., Minocha, S., Kirkup, G., \& Conole, G. (2009). An empirically grounded framework to guide blogging in higher education. Journal of Computer Assisted Learning, 25(1), 31-42. https://doi.org/10.1111/j.1365-2729.2008.00286.x

- Loorbach, N., Peters, O., Karreman, J., \& Steehouder, M. (2014). Validation of the Instructional Materials Motivation Survey (IMMS) in a self directed instructional setting aimed at working with technology. British Journal of Educational Technology, 46(1), 204-218. https://doi.org/10.1111/bjet.12138

- Moore, J.L., Dickson-Deane, C., \& Galyen, K. (2010). E-Learning, online learning, and distance learning environments: Are they the same? Internet and Higher Education, 14(2), 129-135. https://doi.org/10.1016/j.iheduc.2010.10.001

- Naime-Diefenbach, B.N. (1992). Validation of attention and confidence as independent components of the ARCS motivational model.

https://elibrary.ru/item.asp?id=5868350

- National Institute for Statistics in Romania (2015). Sistemul de învă ământ din România. Date statistice. http://www.insse.ro/cms/sites/default/files/field/ publicatii/sistemul_educational_in_romania_2015_2016.pdf

- Nwagbara, C.I. (1994). Effects of the relevance component of the ARCS model of motivational design. https://www.elibrary.ru/item.asp?id=5718791

- OECD (2019). PISA 2018 Results (Volume I): What Students Know and Can Do. OECD Publishing. https://doi.org/10.1787/5f07c754-en

- Park, Y., Heo, G.M., \& Lee, R. (2011). Blogging for informal learning: analyzing bloggers perceptions using learning perspective. Educational Technology and Society, 14(2), 149-160.

https://www.jstor.org/stable/10.2307/jeductechsoci.14.2.149

- Pittenger, A., \& Doering, A. (2010). Influence of motivational design on completion rates in online self-study pharmacy-content courses. Distance Education, 31(3), 275-293. https://doi.org/10.1080/01587919.2010.513953 
- Proiect al Preşedintelui României Klaus Iohannis (2018). România educată. http://www.romaniaeducata.eu/wp-content/uploads/2018/11/Romania-EducataRapoarte.pdf

- Selwyn, N. (2007). Web 2.0 applications as alternative environments for informal learning - a critical review. Paper for OECD-KERIS expert meeting - Session 6 Alternative learning environments in pratice: using ICT to change impact and outcome. http://newinbre.hpcf.upr.edu/wp-content/uploads/2017/02/39458556W2-informal-learning.pdf

- Sharples, M., Taylor, J., \& Vavoula, G. (2005). Towards a theory of mobile learning. Proceedings of mLearn, 1 .

- Streiner, D.L. (2003). Starting at the beginning: An introduction to coefficient alpha and internal consistency. Journal of Personality Assessment, 80(1), 99103. https://doi.org/10.1207/S15327752JPA8001_18

- UmfrageOnline (n.d.). https://www.umfrageonline.com/

- Zoppelt, D., Junesch, L., Hermann, A., \& Mihaiu, T. (2015). Deutschsprachiger Unterricht in Rumänien - ein Überblick über die Wahrnehmung der Stärken, Probleme und Chancen. Schiller Verlag: Bonn-Hermannstadt.

The online version of this article can be found at: http://revped.ise.ro/category/2020-en/

\section{(Cc) $\mathrm{BY}-\mathrm{NC}-\mathrm{SA}$}

This work is licensed under the Creative Commons Attribution-NonCommercial-ShareAlike 4.0 International License.

To view a copy of this license, visit http://creativecommons.org/licenses/by- $n c-s a / 4.0 /$ or send a letter to Creative Commons,

PO Box 1866, Mountain View, CA 94042, USA.
Versiunea online a acestui articol poate fi găsită la: http://revped.ise.ro/category/2020-ro/

\section{$(c c)$ DY-NC-SA}

Această lucrare este licen iată sub Creative Commons Attribution-NonCommercial-ShareAlike 4.0 International License.

Pentru a vedea o copie a acestei licen e, vizita $i$ http://creativecommons.org/licenses/by-nc-sa/4.0/ sau trimite i o scrisoare către Creative Commons, PO Box 1866, Mountain View, CA 94042, SUA. 